\title{
The Study on the Appropriate Workforce Estimation of Clinical Technologists for Job Creation in the Field of Ultrasonic Inspection
}

\author{
Hyung-Joon Bae ${ }^{1, *}$, Dae-Sik Kim,*, Og kyoung Lee, ${ }^{3, *}$ Chul-Seung Kim ${ }^{4, *}$, \\ Sun Young Choi ${ }^{5,+, *}$, Young-Hoi An ${ }^{6, * *}$, Eun-Young Kim ${ }^{7, * *}$, \\ Kun-Woo Kang ${ }^{7, * *}$ and Jin-Yong Jang ${ }^{8, * *}$ \\ ${ }^{I}$ Department of Biomedical Laboratory Science, Daejeon Institute of Science and Technology, Daejeon 35408, Korea \\ ${ }^{2}$ Department of Biomedical Laboratory Science, Dongnam Health University, Suwon 16328, Korea \\ ${ }^{3}$ Department of Clinical Laboratory Science, Daejeon Health Institute of Technology, Daejeon 34504, Korea \\ ${ }^{4}$ Department of Biomedical Laboratory Science, Mokpo Science University, Mokpo 58644, Korea \\ ${ }^{5}$ Department of Biomedical Laboratory Science, Daegu Health Colleg, Daegu 41453, Korea \\ ${ }^{6}$ Seoul National University Hospital, Seoul 03080, Korea \\ ${ }^{7}$ Sungkyunkwan University Samsung Medical Center, Seoul 06351, Korea \\ ${ }^{8}$ Sungkyunkwan University Samsung Changwon Hospital, Changwon 51353, Korea
}

\begin{abstract}
The physiological function test is the only patient contact area in the field of clinical laboratory. We need to recruit and encourage the experts due to requiring the expertise and long time for examination. However, there is currently no rule for estimating optimal workforce in the field of physiological function tests. The purpose of this study is to establish the basis of the studies for mid- to long-long term job creation in the field of ultrasound by evaluating the number of appropriate tests and appropriate workforce. We calculated the quantitative and qualitative workload for the number of appropriate tests and appropriate workforce using online questionnaire. All statistical analyses were performed using SPSS version 18.0 (SPSS Inc., Chicago, IL, USA). A total of 216 respondents were 48 (22.2\%) male and 168 (77.8\%) female. A total of 157 laboratories were 62 (39.5\%) for echocardiography, 91 (58.0\%) for the transcranial Doppler (TCD) and $4(5.7 \%)$ for the carotid ultrasound. The mean number of appropriate tests was $10 \pm 2$ in the echocardiography, 9 \pm 2 in TCD and $11 \pm 2$ in the carotid ultrasound. In addition, the number of laboratories required to recruit employees for appropriate workforce was 19 in echocardiography, 18 in TCD, and 0 in carotid ultrasound. The number of hospital required to recruit workforce were 7 primary hospitals, 22 secondary hospitals, 7 third hospitals. This study can be used as an important data as the first study at present time when the data on the workforce status and work environment of the ultrasonic laboratories is insufficient. Based on the quantitative and qualitative workloads, the number of appropriate tests and appropriate workforce can support mid- to long-long term job creation in the field of ultrasound.
\end{abstract}

Key Words: Echocardiography, Transcranial Doppler, Carotid ultrasound, Workforce

Received: November 25, 2019/ Accepted: December 10, 2019

*Professor, ${ }^{* *}$ Researcher.

${ }^{\dagger}$ Corresponding author: Sun Young Choi. Department of Biomedical Laboratory Science, Daegu Health College, Yeongsong-ro, Buk-gu, Daegu 41453, Korea. Tel: +82-53-320-1307, Fax: +82-53-320-1896, e-mail: kmu5041@ @anmail.net

(C) The Korean Society for Biomedical Laboratory Sciences. All rights reserved.

(9)This is an Open Access article distributed under the terms of the Creative Commons Attribution Non-Commercial License (http://creativecommons.org/licenses/by-nc/3.0/) which permits unrestricted non-commercial use, distribution, and reproduction in any medium, provided the original work is properly cited. 
Table 1. The weight of qualitative workload

\section{서 론}

고령화 시대에 접어들면서 노인인구의 증가와 함께 노 인성 질환(심뇌혈관질환, 신경계질환, 안과질환, 폐질환 등)이 급격히 증가하고 있다. 이와 더불어 의료의 패러다 임이 '치료'에서 '예방 및 진단'으로 바뀜에 따라 건강검진 이 보편화되고 있으며 검사 결과에 대한 의존도가 증가 하고 있다. OECD (2015)에 따르면 우리나라는 OECD 국 가 중 가장 높은 1 인당 국민의료비를 기록하고 있고, 이 는 의료기기산업 성장에 가장 좋은 기반을 제공하여 고 가의료장비의 수가 $\mathrm{OECD}$ 국가 중 유일하게 증가하는 국 가이다. 따라서 의료장비의 증가와 함께 검사건수 또한 증가함에 따라 검사를 수행할 수 있는 전문 인력의 확보 도 함께 이루어져야 검사 업무의 질적 향상을 가져올 수 있고, 정확하고 효율적인 검사가 수행될 수 있다.

진단검사의학 및 병리검사 분야는 검사장비의 자동화 시스템 구축으로 인력 확대에 한계가 있으나, 생리기능검 사 분야는 임상병리사의 업무에서 유일한 환자접점 분야 로 긴 검사시간과 풍부한 경험에 의한 고도의 전문기술 이 요구되고, 진료과별로 연계되어 있으므로 전문 인력이 절실히 필요하고, 인력 확보가 유리하다. 병원에서 일어 나고 있는 환자안전관련 사고는 여러 원인이 있으나, 전 문성 있는 인력의 적절한 배치가 미흡하거나 한정된 인 력이 여러 업무를 중복하여 시행할 수밖에 없는 환경적 리스크가 매우 크다고 할 수 있다(서인범 외., 2002; 오영 호 외., 2007; 조석주 외., 2007). 특히, 사람을 직접 대상으 로 시행하는 생리학적 검사의 경우는 그 영향이 더욱 크 므로 검사를 신속하고 정확하게 수행할 수 있도록 해당 분야의 전문 인력을 적절하게 산정하고, 확보하여 충분한 인프라를 갖추는 것이 의료의 질을 향상할 수 있는 가장 기본적인 최적의 방법이라고 할 수 있다. 특히 초음파검 사는 실시간으로 영상을 획득하는 검사의 특성으로 검사 자의 정확한 판단과 검사의 질이 환자의 진단과 치료에 미치는 영향이 매우 큰 검사이다(New Medical World Weekly, 2008; Department of Health and Ageing, 2011; 정설희 외., 2014).

최근 쟁점화되고 있는 초음파검사 업무영역에 대해 보 건복지부에서 의사의 지시 하에 임상병리사의 초음파검 사가 가능하다는 유권해석을 받았기에 영역 확대 및 고 용 창출에 대한 가능성이 열려 있다. 또한, 체계적인 인 력관리의 미흡과 업무영역에 대한 불분명한 구분으로 타

\begin{tabular}{lll}
\hline \hline Examination time & \multicolumn{1}{c}{ Division } & Weight \\
\hline$>90 \mathrm{~min}$ & Higher 10\% & 1.25 \\
$60 \sim 89 \mathrm{~min}$ & Second higher 20\% & 1.125 \\
$30 \sim 59 \mathrm{~min}$ & Middle 40\% & 1 \\
$15 \sim 29 \mathrm{~min}$ & Second Lower 20\% & 0.875 \\
$<15 \mathrm{~min}$ & Lower 10\% & 0.75 \\
\hline
\end{tabular}

직종의 임상병리사의 고유 업무 침범에 대한 우려가 계속 되고 있고, 병원 내 인력 충원의 한계로 임상병리사의 실 업률 또한 증가하고 있는 가운데 업무영역의 분명한 구 분을 통한 임상병리사의 고용 안정과 인력 확보가 필요 한 실정이다.

따라서, 본 연구의 목적은 초음파검사의 적정검사건수 및 적정 인력을 산정하여 초음파검사 분야의 일자리 창출 과 업무영역 확보를 위한 발판을 마련하고자 한다.

\section{대상 및 방법}

\section{대상}

대한생리검사학회에 가입되어 있고 초음파검사 분야에 종사하는 암상병리사 216 명을 대상으로 온라인 설문조사 를 실시하였다.

\section{업무량 분석}

업무량 분석은 김종득 외 (2012) "직무분석을 통한 적정 인력 산정 및 인력운영 효율화 방안 구축 연구"에 따라 분석하였다. 양적 업무량 산출은 표준 업무량 산정방법을 이용하여 산출하였고, 질적 업무량 산출은 업무별 난이도 및 1 건강 평균 검사시간에 따른 가중치를 반영하여 산출 하였다(Table 1,2).

\section{적정검사건수 산정}

초음파검사의 적정검사건수를 분석하기 위해 한국산업 정보연구소 (2016) "시험, 검사기관 적정검사건수 산정방 법 가이드"에 따라 적정검사건수를 분석하였다(Table 3).

\section{적정인력 산정}

김종득 외 (2012) "직무분석을 통한 적정인력 산정 및 인력운영 효율화 방안 구축 연구"에 따라 업무량 분석을 통해 도출된 초과시간과 부족시간을 기반으로 적정 인력 
Table 2. The method of workload analysis

\begin{tabular}{lll}
\hline \hline \multicolumn{1}{c}{ Value } & \multicolumn{1}{c}{ Mean } \\
\hline (1) Quantitative workload & Total annual working hours & Method \\
(2) Standard working hours & Annual standard working hours for 1 person & $(365$-holiday) $\times 8$ hours \\
(3) Overtime & Annual overtime for 1 person & Mean annual overtime \\
(4) Qualitative workload & Weight of workload & $\sum$ (Weight) \\
(5) Final workload & Quantitative workload $\times$ Qualitative workload & (1) $\times$ (4) \\
\hline
\end{tabular}

Table 3. The method of the appropriate number analysis

\begin{tabular}{lll}
\hline \hline \multicolumn{1}{c}{ Value } & \multicolumn{1}{c}{ Mean } \\
\hline (1) Standard working hours & Standard working hours for 1 day & \multicolumn{1}{c}{ Method } \\
(2) Examination time & Examination time for 1 case & Real test time + 30 min (lose time) \\
(3) Tester's share & Number of tester & 1.0 \\
(4) Appropriate number of ultrasound & Appropriate number of ultrasound for 1 day & 8 hours/examination time $\times$ (3) \\
(5) Overtime rate & More than 50\% (4 hours) of total working day & 1.5 \\
(6) Maximum number of ultrasound & Maximum number of ultrasound for 1 day & 1 day appropriate number of \\
\end{tabular}

을 산정하였고 양적 업무량과 질적 업무량을 이용하여 positioning map을 작성하여 인력운영의 효율화 방안을 제 시하였다(Fig. 1).

- 업무 부서 일평균 초과근무시간

= 업무 부서 일평균 근무시간 $($ 양적 $\times$ 질적 $)-$

전체 부서 일평균 근무시간

- 부족인원 $=($ 일평균 초과근무시간 $($ 분 $) \times$ 현재 인원 $)$

$\div$ 법정 근무시간(480분)

\section{통계적 분석}

초음파검사와 관련해, 응답자의 기본정보, 산업체 특성, 업무량, 적정인력 산출에 관한 정보, 업무영역 확보에 관 한 정보는 기술통계(descriptive analysis)를 실시하였으며, 의료기관별 응답자의 기본정보, 산업체 특성, 업무량, 적 정인력 산출에 관한 정보, 업무영역 확보의 차이는 교차 분석(cross tab analysis) 및 분산분석(ANOVA)를 수행하였 다. 초음파검사 종사자의 노동 강도에 영향을 미치는 요 인을 분석하기 위해 Logistic regression을 실시하였으며 종 속변수는 노동 강도(1: 많음, 매우 많음, 0 : 매우 적음, 적 음, 보통이다), 독립변수는 기본 응답 특성(6개), 산업체 특 성(3개), 업무량(16개)으로 설정하였다. 분석 절차는 먼저, 단변량 로지스틱회귀분석을 실시하며 여기서 유의수준 $5 \%$ 에서 유의한 변수를 선정하며 단변량 로지스틱회귀분

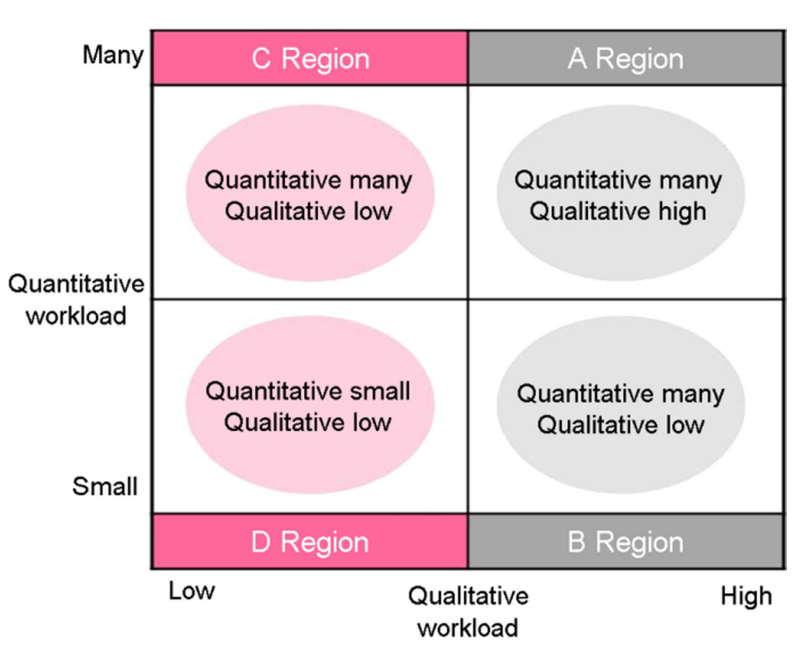

Fig. 1. Positioning map of workload. A region: Overtime hours are relatively high, and the level of difficulty is high. Therefore, this region should be required the recruitment. B region: Overtime hours are relatively low, and the level of difficulty is high. Therefore, focus on quality improvement such as education. C region: There are many hours of work, but the level of difficulty is relatively low, using administrative interns and contract workers. D region: Since both working hours and task difficulty are relatively low, the size of the workforce should be considered when adjusting the capacity.

석에서 유의한 변수를 이용하여 다변량 로지스틱회귀분석 을 실시하였다. 모든 통계분석은 SPSS version 18.0 (SPSS 
Table 4. Baseline characteristics

\begin{tabular}{lc}
\hline \hline \multicolumn{1}{c}{ Value } & Total $(\mathrm{n}=216)$ \\
\hline Age & $61(28.2)$ \\
20 29 & $98(45.4)$ \\
$30 \sim 39$ & $53(24.5)$ \\
$40 \sim 49$ & $4(1.9)$ \\
$50 \sim 59$ & $168(77.8)$ \\
Female & \\
Position & $73(33.8)$ \\
Seoul & $57(26.4)$ \\
Gyeonggi-do & $47(21.8)$ \\
Gyeongsang-do & $20(9.3)$ \\
Chungcheong-do & $17(7.9)$ \\
Jeolla-do & $1(0.5)$ \\
Gandwond-do & $1(0.5)$ \\
Jeju Island & \\
Type of hospital & $21(9.7)$ \\
Primary hospital & $95(44.0)$ \\
Second hospital & $96(44.4)$ \\
Tertiary hospital & $4(1.9)$ \\
Examination center & \\
Type of ultrasound & $88(40.7)$ \\
Echocardiography & $91(42.1)$ \\
Transcranial Doppler & $75(34.7)$ \\
Carotid ultrasound & \\
Type of work & $166(76.9)$ \\
Only ultrasound & \\
Not only ultrasound & \\
\hline & \\
\hline & \\
Ves are & \\
\hline
\end{tabular}

Values are $\mathrm{n}(\%)$ or mean \pm standard deviation

Inc., Chicago, IL, USA)을 이용하였다.

\section{결 과}

\section{기본정보조사}

본 연구에 참여한 응답자의 특성을 Table 4 와 같다. 전 체 응답자 216명 중 여자는 168명(77.8\%)로 나타났고, 연 령대는 30대가 98 명 $(45.4 \%)$ 으로 가장 높게 나타났다. 근 무연수는 5년 이상 10 년 미만의 응답자가 52 명 $(24.1 \%)$ 으로 가장 높게 나타났으며, 근무지역으로는 서울 73 명 (33.8\%), 경기도 57명(26.4\%), 경상도 47명(21.8\%), 충청도 20 명 $(9.3 \%)$ 순으로 나타났다. 의료기관 유형별로는 1 차 의료기관 21 명(9.7\%), 2 차 의료기관 95 명(44.0\%), 3 차 의료
기관 96명(44.4\%), 검진센터 4명(1.9\%) 순으로 나타났다. 검사종류는(중복 응답 가능) 심장초음파 88 명 $(40.7 \%$ ), 뇌 혈류초음파 91명(42.1\%), 경동맥초음파 75명(34.7\%) 순 으로 나타났다. 업무유형으로는 검사 업무만 수행 50명 (23.1\%), 검사 업무 외 다른 업무 함께 수행 166 명(76.9\%) 으로 나타났다.

\section{업무량 분석}

1 일 평균 검사건수, 양적 업무량, 질적 업무량은 Table 5 와 같다. 1 일 평균 검사건수는 심장초음파 12 건, 뇌혈류초 음파 6.5 건, 경동맥초음파 4.5 건으로 분석되었고, 정상 환 자 1 건당 평균 검사소요시간은 심장초음파 17.0 분, 뇌혈 류초음파 24.9분, 경동맥초음파 17.1 분으로 분석되었다. 또 한, 비정상 환자 1 건당 평균 검사소요시간은 심장초음파 31.3 분, 뇌혈류초음파 37.3 분, 경동맥초음파 27.1 분이고 1 일 평균 비정상 환자 비율은 $42.0 \%$ 로 분석되었다. 또한, 1 일 평균 30 분 이상 60 분 미만 소요되는 검사건수는 심 장초음파 5.1건, 뇌혈류초음파 4.4건, 경동맥초음파 2.5건 으로 분석되었고, 1 일 평균 60 분 이상 소요되는 검사건수 는 심장초음파 1.7 건, 뇌혈류초음파 2.2건, 경동맥초음파 2.3 건으로 분석되었다. 1 일 평균 검사건수는 의료기관별 통계적 차이는 없었지만, 정상 환자 1 건당 평균 검사소요 시간 및 비정상 환자의 경동맥초음파의 1 건당 평균 검사 소요시간은 1 차 의료기관에서 통계적으로 적게 분석되었 다. 양적-질적 업무량은 뇌혈류초음파, 심장초음파, 경동 맥초음파 순으로 뇌혈류초음파가 양적·질적 업무량이 가 장 높게 분석되었다. 의료기관 유형별에서는 1 차 의료기 관과 검진센터에서 3 종류 초음파검사에 대한 양적 업무 량이 통계적으로 가장 많은 것으로 분석되었고 $(P<0.001)$, 3 차 의료기관에서는 경동맥초음파에 대한 질적 업무량이 통계적으로 가장 높게 분석되었다 $(P=0.002)$. 하지만 심장 초음파와 뇌혈류초음파의 질적 업무량은 의료기관 유형별 로 통계적 유의한 차이는 없었다.

\section{적정검사건수 산정}

초음파검사 1 일 평균 적정검사건수 산정은 Table 6 과 같다. 전체 의료기관에서는 심장초음파 $10 \pm 2$ 건, 뇌혈류 초음파 $9 \pm 2$ 건, 경동맥초음파 $11 \pm 2$ 건으로 분석되었다. 의 료기관 유형별 심장초음파 $(P=0.696)$, 뇌혈류초음파 $(P=$ $0.174)$ 의 1 일 적정검사건수는 통계적으로 유의한 차이는 없었고, 경동맥초음파는 1 차 의료기관 $12 \pm 1$ 건, 2 차 의료 기관 $11 \pm 2$ 건 3 차 의료기관 $10 \pm 1$ 건으로 통계적으로 유의 
Table 5. The analysis of workload

\begin{tabular}{|c|c|c|c|c|c|c|c|}
\hline Value & Ultrasound & $\begin{array}{c}\text { Total } \\
(n=216)\end{array}$ & $\begin{array}{l}\text { Primary } \\
\text { hospital } \\
(n=21)\end{array}$ & $\begin{array}{c}\text { Secondary } \\
\text { hospital } \\
(\mathrm{n}=95)\end{array}$ & $\begin{array}{l}\text { Tertiary } \\
\text { hospital } \\
(n=96)\end{array}$ & $\begin{array}{c}\text { Examination } \\
\text { center } \\
(\mathrm{n}=4)\end{array}$ & $P$-value \\
\hline \multirow{3}{*}{$\begin{array}{l}\text { Mean number of } \\
\text { ultrasound for } 1 \text { day }\end{array}$} & Echo & $12.0 \pm 5.02$ & $7.8 \pm 4.88$ & $11.9 \pm 5.17$ & $12.6 \pm 4.63$ & $14.0 \pm 8.49$ & 0.163 \\
\hline & TCD & $6.5 \pm 4.67$ & $6.6 \pm 5.02$ & $6.0 \pm 5.02$ & $6.7 \pm 3.85$ & $12.0 \pm 11.31$ & 0.333 \\
\hline & Carotid & $4.5 \pm 3.98$ & $4.4 \pm 3.12$ & $4.6 \pm 4.3$ & $4.6 \pm 4.00$ & - & 0.999 \\
\hline \multirow{3}{*}{ Normal test time } & Echo & $17.0 \pm 7.46$ & $15.8 \pm 3.76$ & $15.9 \pm 7.06$ & $18.5 \pm 8.16$ & $12.5 \pm 3.54$ & 0.318 \\
\hline & TCD & $24.9 \pm 11.03$ & $20.2 \pm 8.40$ & $27.4 \pm 13.1$ & $24.0 \pm 8.57$ & $15.0 \pm 7.07$ & 0.073 \\
\hline & Carotid & $17.1 \pm 9.63$ & $12.50 \pm 6.57$ & $13.8 \pm 9.34$ & $20.4 \pm 9.22$ & - & 0.001 \\
\hline \multirow{3}{*}{ Abnormal test time } & Echo & $31.3 \pm 10.32$ & $30.8 \pm 6.65$ & $29.8 \pm 9.15$ & $32.9 \pm 11.94$ & $30.0 \pm 0.00$ & 0.584 \\
\hline & TCD & $37.3 \pm 15.78$ & $32.1 \pm 14.64$ & $41.2 \pm 18.20$ & $35.3 \pm 12.53$ & $25.0 \pm 7.07$ & 0.088 \\
\hline & Carotid & $27.1 \pm 12.34$ & $20.0 \pm 6.03$ & $24.38 \pm 12.62$ & $30.5 \pm 12.04$ & $10.0 \pm 0.00$ & 0.005 \\
\hline \multirow{3}{*}{$\begin{array}{l}\text { Number of tests } \\
(30 \sim 59 \text { min) for } \\
1 \text { day }\end{array}$} & Echo & $5.1 \pm 6.48$ & $5.0 \pm 2.16$ & $4.6 \pm 7.04$ & $5.8 \pm 6.48$ & $15.0 \pm 0.71$ & 0.764 \\
\hline & TCD & $4.4 \pm 7.51$ & $10.0 \pm 16.79$ & $4.5 \pm 8.24$ & $3.3 \pm 2.17$ & - & 0.137 \\
\hline & Carotid & $2.5 \pm 1.90$ & $3.8 \pm 1.64$ & $2.1 \pm 1.60$ & $2.49 \pm 2.00$ & - & 0.239 \\
\hline \multirow{3}{*}{$\begin{array}{l}\text { Number of tests } \\
(\geq 60 \mathrm{~min}) \text { for } 1 \text { day }\end{array}$} & Echo & $1.7 \pm 1.05$ & - & $1.9 \pm 1.36$ & $1.6 \pm 0.89$ & - & 0.504 \\
\hline & TCD & $2.2 \pm 1.62$ & $3.0 \pm 2.16$ & $1.9 \pm 1.23$ & $2.3 \pm 1.74$ & - & 0.429 \\
\hline & Carotid & $2.3 \pm 1.73$ & $3.5 \pm 2.12$ & $1.5 \pm 1.07$ & $2.6 \pm 1.91$ & - & 0.229 \\
\hline \multirow{3}{*}{$\begin{array}{l}\text { Annual quantitative } \\
\text { workload (hour) }\end{array}$} & Echo & $1.631 \pm 151$ & $1,721 \pm 91$ & $1,645 \pm 148$ & $1,603 \pm 172$ & $1,725 \pm 74$ & $<0.001$ \\
\hline & TCD & $1,652 \pm 214$ & $1,723 \pm 144$ & $1,672 \pm 243$ & $1,598 \pm 133$ & - & $<0.001$ \\
\hline & Carotid & $1,626 \pm 117$ & $1,746 \pm 35$ & $1,639 \pm 123$ & $1,589 \pm 119$ & - & $<0.001$ \\
\hline \multirow{3}{*}{$\begin{array}{l}\text { Annual qualitative } \\
\text { workload }\end{array}$} & Echo & $0.87 \pm 0.09$ & $0.84 \pm 0.06$ & $0.88 \pm 0.08$ & $0.86 \pm 0.10$ & $0.81 \pm 0.09$ & 0.672 \\
\hline & TCD & $0.95 \pm 0.11$ & $0.90 \pm 0.09$ & $0.97 \pm 013$ & $0.92 \pm 0.06$ & - & 0.162 \\
\hline & Carotid & $0.84 \pm 0.08$ & $0.75 \pm 0.09$ & $0.82 \pm 0.08$ & $0.88 \pm 0.08$ & - & 0.002 \\
\hline
\end{tabular}

Values are mean \pm standard deviation. TCD, transcranial Doppler

Table 6. The analysis of appropriate number of ultrasound

\begin{tabular}{llrccrcc}
\hline \hline \multicolumn{1}{c}{ Value } & Ultrasound & Total & $\begin{array}{c}\text { Primary } \\
\text { hospital }\end{array}$ & $\begin{array}{c}\text { Secondary } \\
\text { hospital }\end{array}$ & $\begin{array}{c}\text { Tertiary } \\
\text { hospital }\end{array}$ & $\begin{array}{c}\text { Examination } \\
\text { center }\end{array}$ & $P$-value \\
\hline \multirow{3}{*}{$\begin{array}{l}\text { Mean appropriate } \\
\text { number for 1 day }\end{array}$} & Echo & $10 \pm 2$ & $11 \pm 1$ & $10 \pm 2$ & $10 \pm 2$ & $11 \pm 1$ & 0.696 \\
& TCD & $9 \pm 2$ & $10 \pm 2$ & $9 \pm 2$ & $9 \pm 1$ & & 0.174 \\
& Carotid & $11 \pm 2$ & $12 \pm 1$ & $11 \pm 2$ & $10 \pm 1$ & 0.006 \\
\hline
\end{tabular}

Values are mean \pm standard deviation. TCD, transcranial Doppler

한 차이는 있었다 $(P=0.006)$.

\section{적정인력 산정}

초음파검사 종류에 따른 업무부서별 및 의료기관 유형 별 부족인원 산정 결과는 Table 7과 같다. 총 154 개 업무 부서에서 42개(27.6\%)의 부서가 0 1명 부족하였고, 세부 부서로는 심장초음파 14 개, 뇌혈류초음파 28 개 부서로 분 석되었다. 의료기관 유형으로는 1 차 의료기관 9 개 2 차 의
료기관 15 개, 3 차 의료기관 17 개, 검진센터 1 개 부서에서 0 1명 부족으로 분석되었다. 적정 인력을 보유한 부서는 101 개(65.1\%), 과잉 인력을 보유한 부서는 10 개(6.6\%)로 분석되었다.

\section{Positioning map에 따른 인력운영 효율화 방안}

초음파검사 종류에 따른 업무 부서별 및 의료기관 유형 별 업무량 현황은 Table 8 , 인력운영 효율화 방안은 Table 
Table 7. The analysis of appropriate workforce

\begin{tabular}{|c|c|c|c|c|c|c|}
\hline \multirow{2}{*}{ Type } & Ultrasound & $0<$ Excess $\leq 1$ & 0 & $0<$ Lack $\leq 1$ & $1<$ Lack $\leq 2$ & Total \\
\hline & $\mathrm{n}(\%)$ & $10(6.58)$ & $101(65.13)$ & $42(27.63)$ & $1(0.66)$ & 154 \\
\hline \multirow{3}{*}{ Laboratory } & Echo & $6(10.2)$ & $38(64.4)$ & $14(23.7)$ & $1(1.7)$ & 59 \\
\hline & TCD & $3(3.3)$ & $60(65.9)$ & $28(30.8)$ & 0 & 91 \\
\hline & Carotid & $1(25.0)$ & $3(75.0)$ & 0 & 0 & 4 \\
\hline \multirow{4}{*}{ Hospital } & Primary hospital & 0 & $10(52.6)$ & $9(47.4)$ & 0 & 19 \\
\hline & Secondary hospital & 2 & 60 & 15 & 0 & 77 \\
\hline & Tertiary hospital & 8 & 30 & 17 & 1 & 56 \\
\hline & Examination center & 0 & 1 & 1 & 0 & 2 \\
\hline
\end{tabular}

Values are n (\%).TCD, transcranial Doppler

Table 8. The distribution of workload

\begin{tabular}{|c|c|c|c|c|c|c|c|c|}
\hline & \multirow{3}{*}{ Type } & & \multicolumn{6}{|c|}{ Quantitative workload } \\
\hline & & & \multicolumn{2}{|c|}{ Echo } & \multicolumn{2}{|c|}{ TCD } & \multicolumn{2}{|c|}{ Carotid } \\
\hline & & & Small & Many & Small & Many & Small & Many \\
\hline \multirow{10}{*}{$\begin{array}{l}\text { Qualitative } \\
\text { workload }\end{array}$} & \multirow{2}{*}{ Total } & Low & 7 & 11 & 23 & 27 & 0 & 2 \\
\hline & & High & 22 & 19 & 23 & 18 & 2 & 0 \\
\hline & \multirow{2}{*}{ Primary hospital } & Low & 0 & 1 & 0 & 9 & 0 & 0 \\
\hline & & High & 1 & 4 & 1 & 3 & 0 & 0 \\
\hline & \multirow{2}{*}{ Secondary hospital } & Low & 4 & 8 & 9 & 12 & 0 & 0 \\
\hline & & High & 10 & 11 & 12 & 11 & 0 & 0 \\
\hline & \multirow{2}{*}{ Tertiary hospital } & Low & 3 & 2 & 14 & 5 & 0 & 2 \\
\hline & & High & 11 & 3 & 10 & 4 & 2 & 0 \\
\hline & \multirow{2}{*}{ Examination center } & Low & 0 & 0 & 0 & 1 & 0 & 0 \\
\hline & & High & 0 & 1 & 0 & 0 & 0 & 0 \\
\hline
\end{tabular}

Values are n. TCD, transcranial Doppler

Table 9. The efficiency of the workforce management

\begin{tabular}{llccrr}
\hline \hline \multirow{2}{*}{ Type } & \multicolumn{1}{c}{ Ultrasound } & Recruitment & $\begin{array}{c}\text { Improvement of } \\
\text { qualitative } \\
\text { workload }\end{array}$ & $\begin{array}{c}\text { Use of interns or } \\
\text { contract worker }\end{array}$ & Reduction \\
\hline \multirow{3}{*}{ Laboratory } & Echo & 19 & 22 & 11 & 7 \\
& TCD & 18 & 23 & 27 & 23 \\
\hline \multirow{3}{*}{ Hospital } & Carotid & 0 & 2 & 2 & 0 \\
& Primary hospital & 7 & 22 & 20 & 0 \\
& Secondary hospital & 22 & 23 & 9 & 13 \\
\hline Total=154 & Tertiary hospital & 7 & 0 & 1 & 17 \\
\hline
\end{tabular}



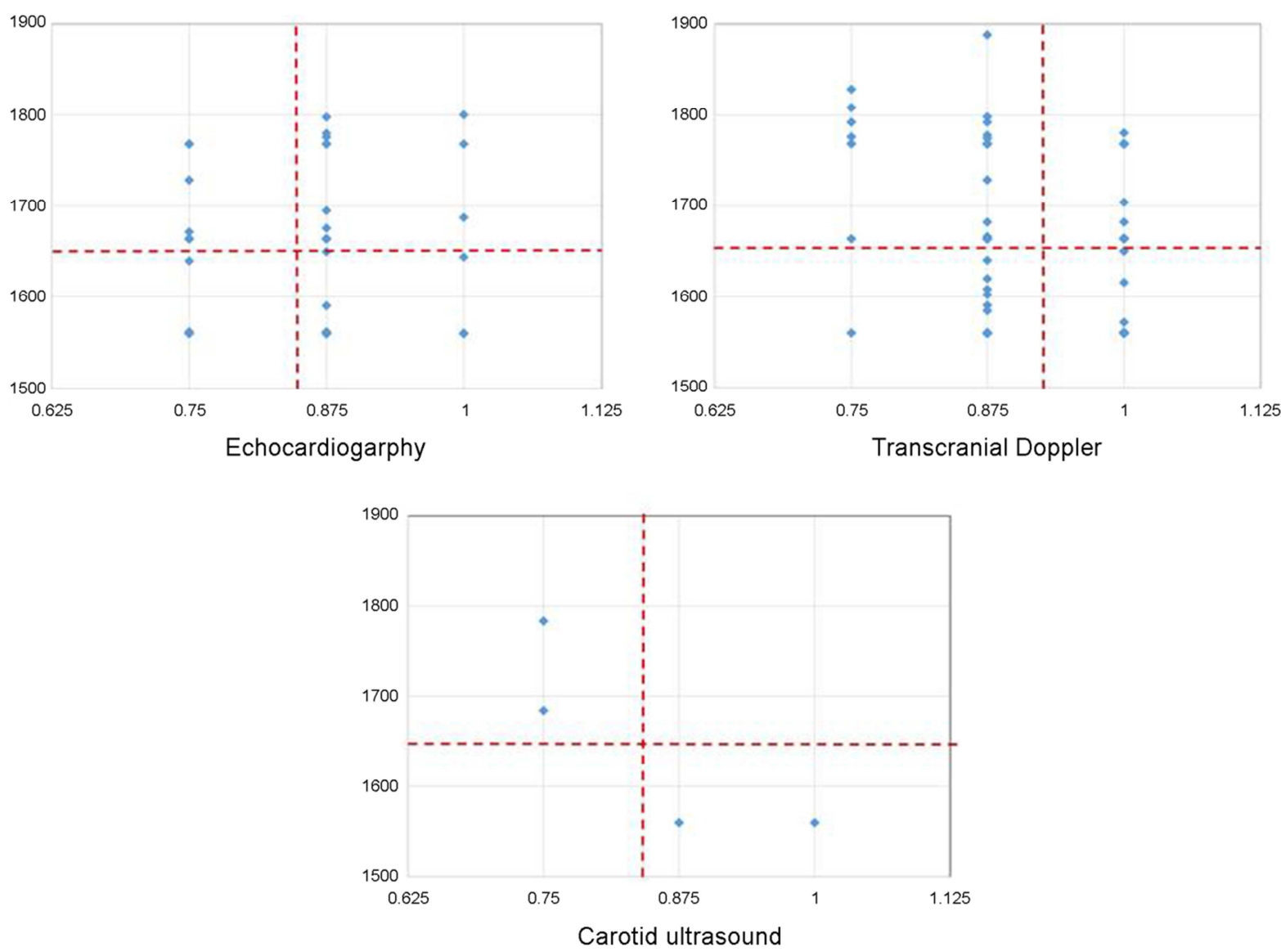

Fig. 2. Positioning map of workload according to laboratory.

9 와 같다. 총 154 개 부서에서 양적 업무량 및 질적 업무 량이 모두 많아 인력 충원이 필요한 부서는 37개(24.0\%) 로 심장초음파 19 개, 뇌혈류초음파 18 개, 경동맥초음파 0 개로 부서로 분석되었으며, 의료기관 유형으로는 1 차 의 료기관 7개, 2 차 의료기관 22 개, 3 차 의료기관 7 개, 검진센 터 1 개로 부서로 분석되었다. 양적 업무량이 많고 질적 업무량이 적어 계약직 활용이 필요한 부서는 37개(24.7\%) 로 심장초음파 11 개, 뇌혈류초음파 27 개, 경동맥초음파 2 개로 분석되었으며, 의료기관 유형으로는 1 차 의료기관 10 개, 2 차 의료기관 20 개, 3 차 의료기관 9 개, 검진센터 1 개 로 분석되었다. 검사의 난이도가 높은 질적 업무량 향상 이 필요한 부서는 47 개(30.5\%)로 심장초음파 22개, 뇌혈 류초음파 23 개, 경동맥초음파 2 개로 분석되었으며, 의료 기관 유형으로는 1 차 의료기관 2 개, 2 차 의료기관 22 개, 3 차 의료기관 23 개, 검진센터 0 개로 분석되었다. 양적 업 무량 및 질적 업무량이 모두 적어 인력 축소가 필요한 부 서는 30개(19.5\%)로 심장초음파 7개, 뇌혈류초음파 23개,

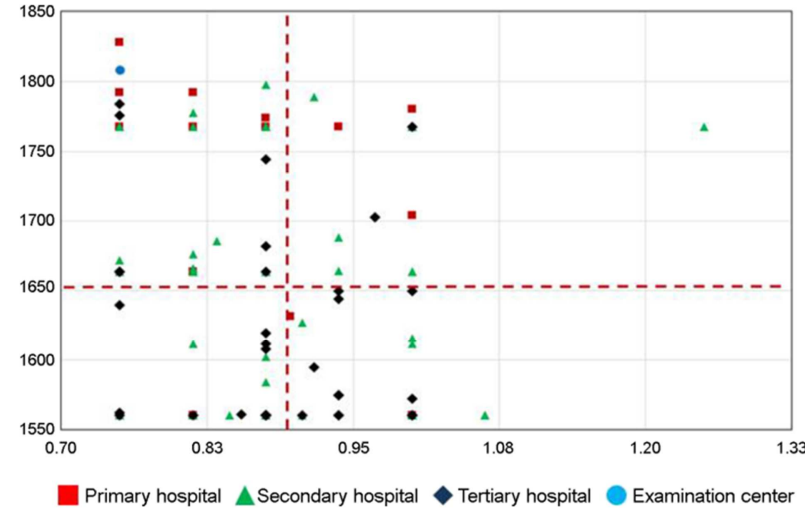

Fig. 3. Positioning map of workload according to hospital

경동맥초음파 0 개로 분석되었으며, 의료기관 유형으로 는 1 차 의료기관 0 개, 2 차 의료기관 13 개, 3 차 의료기관 17 개, 검진센터 0 개로 분석되었다. 인력운영 효율화를 위 한 positioning map은 Fig. 2,3과 같다. 


\section{고 찰}

본 연구는 크게 2가지로 요약할 수 있다. 초음파검사 1 일 적정검사건수는 심장초음파 평균 10 건, 뇌혈류초음파 평균 9 건, 경동맥초음파검사 평균 11 건으로 분석되었다. 전체 127 개 의료기관의 154 개 부서에서 인력 충원이 필 요한 부서는 37개(24.0\%)로 심장초음파 19개, 뇌혈류초음 파 18 개, 경동맥초음파 0 개로 부서로 분석되었으며, 의료 기관 유형으로는 1 차 의료기관 7 개, 2 차 의료기관 22 개, 3 차 의료기관 7 개, 검진센터 1 개로 부서로 분석되었다. 이 처럼 초음파검사 항목별 업무량을 파악하고 적정 인력을 산출하여 일자리를 창출함으로써 업무 부서별 인력운영의 효율성을 극대화하여 검사의 질을 향상시키고, 임상병리 사의 초음파검사 분야 고용 안정과 업무영역 확보를 발 판을 마련하는데 의미가 있다고 생각된다.

보건의료 인력은 가장 핵심적인 보건의료 자원으로 한 국가의 보건의료 인력의 양과 질은 그 국가의 의료 수준 을 가능할 수 있는 결정적 기준으로 이용되고 있으며, 단 기간에 수급을 조절할 수 없는 보건의료 인력의 특성상 잘못된 수급 정책은 장기간에 걸쳐 국가 의료시스템의 비효율성을 초래할 수 있다. 또한, 의료 인력의 수와 질 은 의료공급의 주요 결정 요인이 되고 있어 의료 인력의 적정 수준 유지는 국민 건강권 확보를 위해 필수적이다. 특히 국민소득과 교육 수준 및 생활 수준이 향상되면서 국민의 건강에 대한 관심이 고조되고, 평균수명의 연장으 로 인한 인구의 고령화 추세, 건강보험의 보장성 확대 등 으로 의료 수요는 계속 증가되고 있기 때문에 이에 대응 하는 적정 서비스의 공급과 확보는 국민 복지 차원에서 필수적인 요소가 되었다(오영호 외., 2016). 인구의 고령화 와 질병구조의 변화, 의학기술의 발달과 의료서비스의 다 양화 고도화와 함께 의료를 받아들이는 오늘날의 의료 환경 변화에 의료관련 직종 전체가 대응하기 위해서는 의료관련 직종간의 효율적이고 적정한 역할분담과 소통 이 필요하다. 보건의료공급체계가 제대로 확립되기 위해 서는 앞으로의 사회 변화에 대응할 수 있고 보건의료서 비스 각각의 영역에서 필요한 인력이 뒷받침되어야 하며 기존 인력의 역할과 기능을 업그레이드시키고 새로운 인 력을 개발해야 한다.

의료 인력의 공급 측면과 수요 측면의 방안들이 효율 적이기 위해서는 관련 법과 제도를 개선하고 인프라를 구축할 필요가 있으며, 이러한 법과 제도적 개선은 의료
적 타당성 및 인력수급 현황을 두루 고려해 인력고용을 통해 의료서비스의 질이 향상될 수 있는 방향으로 검토되 어야 한다. 또한, 보건의료환경의 변화에 적절하게 대응하 고 의료서비스의 질을 높이기 위해서는 현재의 의료환경 현황 분석 및 보건의료 인력의 실태파악과 수급전망을 통하여 보건의료 인력을 적정하게 양성하고 적재적소에 배분하는 것이 필요하다(박용철 외., 2015). 따라서 본 연 구는 초음파 분야에 종사하는 임상병리사들을 대상으로 설문조사를 실시하여 업무량 및 근무실태를 파악하고 적 정검사건수 및 적정 인력을 산출함으로써 일자리 창출을 위한 근거를 마련하고 있어 의미 있는 연구라고 할 수 있다. 초음파검사실의 효율적인 운영은 단순한 경제적인 측면 외에 국민건강에 중요한 영향을 주므로 검사의 질 도 매우 중요하다. 검사실의 효율적인 운영에 대한 평가 는 효율성과 생산성으로 평가할 수 있고, 선행 연구(오영 회 외., 2007)에서 의료 인력 중 의사, 간호사, 간호조무사 에 비하여 의료기사의 평균 생산성이 가장 높다고 발표 한 바 있으며 경영자는 효율성 및 생산성 측면에서 검사 실의 업무 수행에 있어서 적절한 인력을 보유하고 있는 지, 검사자가 검사의 난이도에 충분한 경력과 풍부한 경 험을 가지고 있는지의 여부를 고려해야 한다.

우리나라 의료기관의 초음파검사 장비 보유 현황은 병 원급 이상 의료기관은 대부분 초음파검사 장비를 보유하 고 있는 것으로 나타났다(정설희 외., 2014). 이처럼 초음 파검사 장비의 확산이 많이 이루어진 상황에서, 초음파검 사 장비 사용의 보편성, 장비 발전으로 인한 검사 적용범 위의 확대, 타 영상진단검사 대비 저렴한 비용 등에 힘입 어 관련 수요는 계속 증가할 것으로 전망되므로 초음파 검사의 질 관리가 매우 필요한 시점이다. 초음파검사는 검사자가 검사를 시행함과 동시에 실시간 영상을 판독하 여 진단에 필요한 영상을 획득하기 때문에 검사자에 대 한 의존도가 높고, 검사자의 지식과 경험에 따라 그 차이 가 발생할 수 있다(New Medical World Weekly, 2008; Department of Health and Ageing, 2011; 정설희 외., 2014). 검사자의 역량에 따른 이러한 차이는 검사 결과를 크게 좌우할 수 있기 때문에 제공 인력의 질 관리가 중요하며, 특히 검사자의 지속적인 교육이 매우 중요하다. 본 연구 의 결과에서도 질적 업무량이 높은 의료기관의 질 관리 가 특히 중요할 것으로 사료된다.

\section{연구 한계점}

본 연구는 설문조사방법으로 진행된 연구로써 다음과 
같은 한계점이 있다. 첫째, 전체 초음파검사자들의 의견 및 업무환경을 대변하지 못하였고, 설문조사 당시 주관적 견해가 반영되었을 가능성을 배제하지 못한다는 점이 있 다. 둘째, 적정검사건수 및 적정인력 산출 시, 초음파검사 업무만을 수행한다는 가정 하에 분석하였고, 각 의료기관 의 부서 특성상 초음파검사 외 검사 업무 및 다른 업무 를 수행하는 경우, 그 업무들의 업무량을 반영하지 못하 였기 때문에 본 연구 결과에 산출된 적정검사건수 및 적 정 인력을 적용하기에 한계가 있다. 셋째, 의료기관의 부 서 특성상 초음파검사소요시간 및 검사의 난이도가 다 양하여 평균 적정검사건수 및 적정인력 수는 의료기관 특성상 차이가 있을 수 있다. 넷째, 본 연구의 의료기관 유형은 1 차 병원 $10 \%, 2$ 차 병원 $44 \%, 3$ 차 병원 $44 \%$ 로 분 석되었으므로 1 차 병원의 업무환경을 충분히 반영하지 못 하였다.

결론적으로, 양적·질적 업무량을 바탕으로 적정 인력 을 산출하여 업무 부서별 인력운영의 효율성을 극대화함 으로써 검사의 질을 향상시킬 수 있으며, 일자리를 창출 하여 초음파검사 분야 고용 안정과 업무영역 확보의 발 판을 마련하는데 본 연구의 의미가 있다고 생각된다. 또 한, 초음파검사실의 인력 구조 및 업무환경에 대한 자료 가 미흡한 현 시점에서 중요한 자료로 활용될 수 있을 것으로 사료된다.

\section{ACKNOWLEDGEMENT}

본 연구는 대한임상병리사협회의 연구과제 연구비로 진행되었다.

설문조사에 응해주신 대한임상병리사협회 회원분들께 진심으로 감사드립니다.

\section{CONFLICT OF INTEREST}

The author declares no conflict of interest.

\section{REFERENCES}

김종득, 진대선. 직무분석을 통한 적정인력 산정 및 인력
운영 효율화 방안 구축 연구. 국민권익위원회. 2012. 박용철, 곽상신. 보건의료산업 인력 수급 및 근로조건 개선 방안 연구용역. 워크인조직혁신연구소. 2015.

서인범, 마경란, 이승무, 권전아, 배숙영, 윤수영, 임채승, 이 갑노. 국내 임상병리검사실의 인력구조 및 운영 현황 II. 임상검사와 정도관리. 2002. 24: 237-242.

오영호, 신호성, 이상영, 김진현. 보건의료 인력자원의 지 역별 분포의 적정성과 정책과제. 한국보건사회연구원. 2007-02.

오영호, 이상영. 보건의료 환경 변화에 따른 중장기 의료 인력 추계와 정책과제. 한국보건사회연구원. 2016-06. 조석주, 김상아, 박웅섭. 의료보의원조인력이 건강보험 진 료비와 환자수에 미치는 영향. 보건행정학회지. 2007. 17: 18-32.

정설희, 이혜진, 김한상, 오주연 주요국의 초음파검사 시행 현황과 질 확보방안. 보건행정학회지. 2014. 24: 109-119. 한국산업정보연구소. 시험·검사기관 적정검사건수 산정가이 드 개발. 식품의약품안전처. 2016.

Department of Health and Ageing.Use of ultrasound by (nonradiology) medical specialists across Australia. Canberra: Department of Health and Ageing. 2011.

New Medical World Weekly. Discussion: aiming to enhance the engineer education and ultrasound screening [Internet]. Tokyo: New Medical World. 2008

OECD Health Data. OECD 2011 2015.
https://doi.org/10.15616/BSL.2019.25.4.381

Cite this article as: Bae HJ, Kim DS, Lee Ok, Kim CS, Choi SY, An YH, Kim EY, Kang KW, Jang JY. The Study on the Appropriate Workforce Estimation of Clinical Technologists for Job Creation in the Field of Ultrasonic Inspection. Biomedical Science Letters. 2019. 25: 381389. 